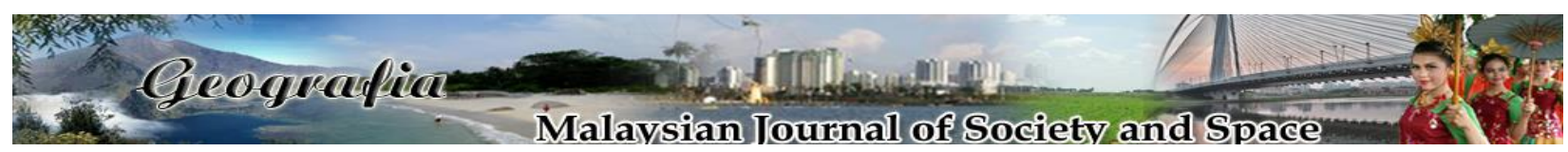

\title{
Impact of changes in climatic elements on crop yield in Kwara State: A comparative analysis between grains and root tubers
}

\author{
A.M. Tunde \\ Department of Geography \& Environmental Management, University of Ilorin, Nigeria \\ Correspondence: A.M. Tunde (email: folamoni70@yahoo.com)
}

Received: 21 December 2018; Accepted: 15 March 2019; Published: 14 May 2019

\begin{abstract}
This study presents a comparative analysis on the effects of climatic variations on crop yield in Kwara State using grains and root tubers. Annual climatic and crop yield data for a period of twenty years (1998-2017) were collected from Kwara State Agricultural Development Project. Climatic data obtained includes rainfall, number of rainy days, relative humidity, maximum and minimum temperature. Grain crops and root tubers' data include maize, sorghum, rice, millet, cowpea, soya beans and cassava, yam, sweet potato respectively. These were however subjected to trend, correlation and multiple regression analyses. The results obtained revealed that changes in climatic elements have impact on both grains and root tubers' yield although low but in combination with other factors such as edaphic, farm techniques and seed varieties among others. The regression result revealed that the variance in maize, sorghum, rice, millet, cowpea and soya beans respectively be explained by the climatic elements under study. Similarly, of the variance in cassava, yam, and sweet potato respectively can also be explained by the climatic elements under study. Hence, there is no significant difference in impacts of changes in climatic elements between grains and root tuber. Therefore, it can be concluded that the changes in climatic elements can be seen as part of the factors responsible for low agricultural yield and production in the state and country at large. Policies that will improve the status of agricultural yield and production should therefore, be embarked upon.
\end{abstract}

Keywords: agricultural yield, climate, crops, elements, grains, root tubers

\section{Introduction}

Agriculture remains as an important sector in Nigeria's economy and the mainstay of the majority of households. The rate of decline in agricultural production in Nigeria however, is alarming and worrisome. One now wonders what could have been responsible for this despite the fact that almost everybody in all works of life at the rural and urban areas is into one form of agriculture or the other. Chen and Ravalion (2007) reported that seventy percent of poor Nigerians resides in the rural areas and to a large extent depends primarily on agriculture for 
their sustenance. Furthermore, Hovorka and Lee-Smith (2004) reported that the international development community has promoted and embraced agriculture as a means for urban dwellers to achieve sustainable livelihoods and socio-economic advancement internationally. This signifies how important agriculture is, at both national and international levels.

Food production and security is a crucial issue of international concern. This can be linked with the current high population growth rate globally (Ayantoye et al., 2011). In Nigeria, the rate of increase in population is also alarming that the last 2006 population census put the population of Nigeria at 140 million people. Hence the rate of food production cannot keep pace with the population increase although, agricultural production in Nigeria like most African countries is vulnerable to the impact of changes in climatic elements. This is because agriculture in Nigeria like most African countries is rain-fed. Small scale farmers in the country can no longer predict incidence of rain based on past observation.

Climatic change according to Thompson and Amos (2010) is the decrease or increase in the average temperature of the earth's near-surface air and oceans since the mid- $20^{\text {th }}$ century and its projected continuation. Global climate change is projected to have important regional effects on agriculture and food production for man's use and consumption (US Global Change Research Program, 2003). Variations in relative humidity, sunshine and particularly temperature and rainfall, can have severe adverse effects on agricultural practices and the yields of both food crops as well as on animal production potential (Thompson \& Amos, 2010). Elijah et al. (2018) reported that unpredictable variation in the onset of rains in the last few years have led to situations where crops planted with the arrival of early rains get smothered in the soil by an unexpected dry spell, resulting in harvest failures in Nigeria. Similarly, Ajadi et al. (2011) observed that crop yield and livestock productivity are determined by temperature, moisture and other climatic parameters.

Kurukulasuriya and Rosenthal (2003) identified the four ways in which climate affect agricultural production; changes in temperature and precipitation directly affect crop production which can lead to variation in the distribution of agro-ecological zones; increased $\mathrm{CO}_{2}$ is expected to have a positive impact on agricultural production due to greater water use efficiency and higher rates of plant photosynthesis; water availability is necessary in determining the impact of climate change on crop production, especially in Africa, and agricultural losses can result from climate variability and the increased frequency of changes in temperatures and precipitation (including drought and floods).

It is a well-known fact that several studies have been carried out by different scholars (Kurukulasuriya \& Mendelsohn, 2006; IISD, 2007; Lobell et al., 2008) in developing countries including Nigeria on climate change and agricultural production. The results have revealed that climatic variables over the past years affect agricultural production. Despite this, adequate attention has not been given to climatic impact on crop production in Nigeria particularly in Kwara State. Furthermore, comparative analysis of the impact of changes in climatic elements on grains and root tuber has received little or no attention in Kwara State. It is however important to find out whether there will be any significant difference between impact of climatic elements on grains and root tubers in the study area and also between the past and the present study. It is against this background that this study makes a comparative analysis between the impact of climatic elements on grains and root tuber yield in Kwara State, Nigeria over a period of 20 years (1998-2017). Specifically, the study will assess the relationship between climatic variables and crop yield under examination, analyze the pattern of climatic variables and crop yield for a 
period of 20 years (1998-2017) and finally suggest recommendations to improve crop yield and production in the study area.

\section{Literature review}

\section{Climatic parameters and crop production}

Climate is the most important factor determining plant growth and yield. Its major parameters include rainfall, temperature and relative humidity.

\section{a. Rainfall}

Water in its different forms plays a significant role in the growth of plants and the production of all crops (Ayoade, 2004). Rainfall according to Barry and Chorley (2003) is a form of precipitation that occurs in many areas of the world. In terms of distribution, it varies over time and space and a very crucial factor in crop production in Nigeria. In relation to crop production, rainfall is guided by factors such as number of rainy days, total amount of fall, time of fall and the type of soil. Rainfall usually determines the type of crop to be grown in different environment as well as the type of agricultural system to be practiced in different parts of the country. The rainfall requirement of some food crops according to Ayoade (2004) is as shown in Table 1.

Table 1. Mean annual rainfall required for some selected crops

\begin{tabular}{lc}
\hline Crops & Mean annual rainfall $(\mathbf{m m})$ \\
\hline Groundnut & $500-1000$ \\
Yam & At least 1250 \\
Cocoa & $1250-2000$ \\
Kolanut & At least 1250 \\
Maize & $500-800$ \\
Rice & $1400-1800$ \\
Soya beans & $1250-1500$ \\
Oil palm & $1500-3000$ \\
Rubber & $2000-2500$ \\
Cotton & $652-1250$ \\
\hline
\end{tabular}

Source: Ayoade, 2004.

\section{b. Temperature}

Temperature can be defined as the degree of hotness or coldness of a body and is measured by a thermometer with maximum and minimum values. Air temperature varies from place to place over time. Temperature of the air and soil usually affects the processes of growth of plants and animals. Every crop has minimum, optimum and maximum temperature limits of each of their stages of growth. For instance, cocoa require high temperature throughout the year. Table 2 shows the optimum temperature for some selected crops. 
Table 2. Optimum temperature for the growth of some selected crops

\begin{tabular}{lc}
\hline Crops & Optimum temperature \\
\hline Rice & $25-35^{\circ} \mathrm{C}$ \\
Cassava & $25-29^{\circ} \mathrm{C}$ \\
Soya beans & $25^{\circ} \mathrm{C}$ \\
Sweet Potato & $16^{\circ} \mathrm{C}$ \\
Yam & $25^{\circ} \mathrm{C}$ \\
Maize & $28^{\circ} \mathrm{C}$ \\
Sorghum & $16-32^{\circ} \mathrm{C}$ \\
Groundnut & $21-35^{\circ} \mathrm{C}$ \\
Millet & $45-50^{\circ} \mathrm{C}$ \\
Cowpea & $16^{\circ} \mathrm{C}$ \\
\hline
\end{tabular}

Source: Ayoade, 2004

The rate of physio-chemical reaction, evaporation of water from crops and soil surface is been controlled by temperature in cereal crops (Ismaiala et al., 2010). Studies have shown that with increase in temperatures as a result of global warming, productivity in rice and other tropical crops decreases. For instance, high temperature of about 1 to 2 hours at anthesis causes large percentage of grain sterility in rice (Nguyen, 2006).

\section{c. Relative humidity}

Humidity can be defined as the amount of water vapor present in the air. Amount of water vapor at any location usually decrease with altitude. This is because both atmospheric temperature and pressure decreases with increased height above ground level. Hence, the hotter the air temperature, the faster the transpiration rate from the plant although, high humidity at night is beneficial to some plants. Plant growth generally depends on high atmospheric humidity because they have the ability to directly absorb moisture from unsaturated air of high humidity.

\section{Methods and study area}

Kwara State (Figure 1) is the study area for this research work. It is located between latitudes $8^{\circ}$ and $10^{\circ} 04^{1} \mathrm{~N}$ and longitudes $2^{\circ} 45^{1} \mathrm{E}$ and $6^{\circ} 12^{1} \mathrm{E}$. The state shares boundaries with Niger State in the north, Kogi and Ekiti States at the east, Osun and Oyo States in the south and an international boundary with the Republic of Benin in the west. It occupies an area of $36,825 \mathrm{~km}^{2}$ and consists of sixteen Local Government Areas.

The climate of the state is tropical with a distinct dry and rainy season. The rainy season on the average lasts for nine months between March and October or sometimes early November with a mean annual rainfall of 1,000 to $1,500 \mathrm{~mm}$. The dry season is about four months from November to February and sometimes times it may extend to early March. Temperatures are usually higher during the dry season than rainy season. The mean maximum temperature usually ranges between $33^{\circ} \mathrm{C}$ and $36^{\circ} \mathrm{C}$ while the mean minimum temperature ranges between $19^{\circ} \mathrm{C}$ and $24^{\circ} \mathrm{C}$ for a greater part of the year (November-March). The absolute minimum and maximum temperature during this period ranges between $15^{\circ} \mathrm{C}-20^{\circ} \mathrm{C}$ and $35^{\circ} \mathrm{C}$ respectively (Ajibade, 2002). The vegetation, is mainly the wooded Savannah, and well suited for the cultivation of a wide variety of food crops such as maize, cassava, yams, rice, groundnut, sorghum, fruits, and vegetables, among others. 


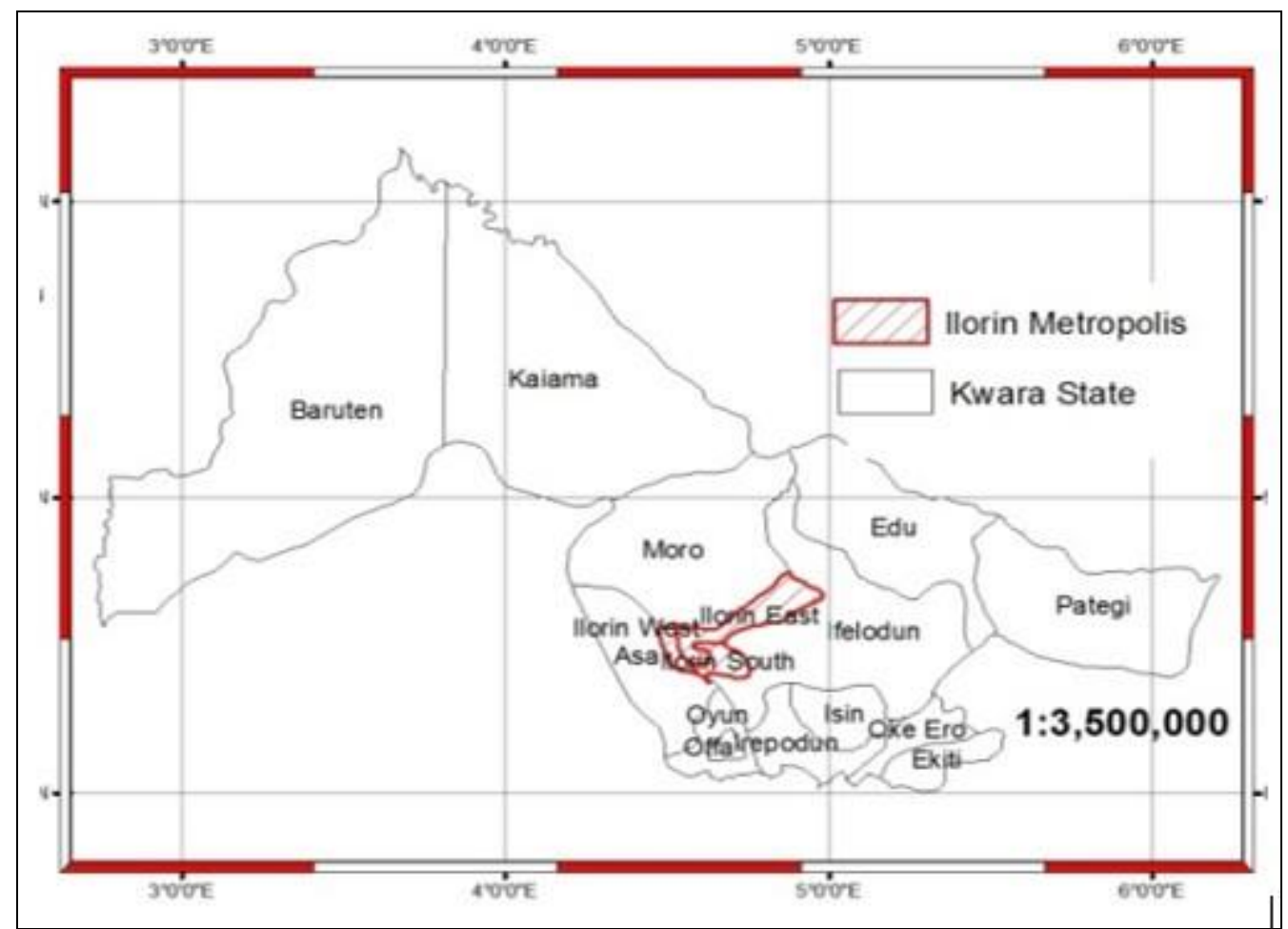

Source: Kwara State Ministry of Lands, 2017

Figure 1. Kwara State showing the LGAs and Ilorin the state capital

The study area consists of a large proportion of ferruginous tropical soils. These soils are reddish in colour and have appreciable reserve of weatherable minerals. Similarly, alluvial and hydromorphic soils on the banks of River Niger have strong potentials for agricultural activities. The soils in the state consist of adequate calcium, potassium, magnesium and phosphorus that can be tapped by the crops grown on them. The justification for chosen the state was because of its high potentials for agricultural production generally.

Secondary source of information was employed for this study. Data for this study were obtained from Kwara State Agricultural Development Project (KWADP). Data obtained included climatic data and crop yield data over a period of twenty (20) years (1998-2017). The climatic data (Table 3) obtained in the archive of KWADP are rainfall, number of rainy days, relative humidity maximum and minimum temperature while crop yield data (Table 4) obtained includes maize, cassava, yam, sorghum, rice, millet, cowpea, soya beans and sweet potato for all the ecological zones. All the climatic parameters and selected common crops in the State were subjected analysis.

Descriptive and inferential statistical techniques were employed to analyze the data gathered. Descriptive statistics employed include tables while inferential statistics employed include trend, correlation and multiple regression analyses. This is in order to observe and compare strength of relationships between climatic elements and crop yield over the period under study for Kwara State, Nigeria. Regression analysis was estimated with the formula $Y=a$ + bx, where;

$\mathrm{Y}=$ dependent variable

$\mathrm{x}=$ independent variable 
$\mathrm{a}=$ intercept on $\mathrm{y}$-axis

$\mathrm{b}=$ slope coefficient

Climatic variables represent the independent variable while the dependent variable is crop yield.

Table 3. Mean annual climatic data for Kwara State (1998-2017)

\begin{tabular}{cccccc}
\hline Year & $\begin{array}{c}\text { Rainfall } \\
(\mathbf{m m})\end{array}$ & $\begin{array}{c}\text { Relative } \\
\text { humidity }\end{array}$ & $\begin{array}{c}\text { Maxi. temp } \\
\left(\mathbf{(}^{\mathbf{O}} \mathbf{C}\right)\end{array}$ & $\begin{array}{c}\text { Min. temp } \\
\left({ }^{\mathbf{O}} \mathbf{C}\right)\end{array}$ & $\begin{array}{c}\text { Number of } \\
\text { rainy days }\end{array}$ \\
\hline 1998 & 1104.50 & 0.00 & 35.71 & 21.30 & 72 \\
1999 & 1292.30 & 0.00 & 34.82 & 21.89 & 80 \\
2000 & 946.70 & 78.00 & 37.93 & 22.08 & 56 \\
2001 & 907.60 & 76.00 & 40.06 & 19.79 & 57 \\
2002 & 1028.50 & 77.00 & 36.44 & 20.30 & 66 \\
2003 & 811.75 & 83.00 & 31.17 & 17.50 & 50 \\
2004 & 1597.40 & 82.00 & 33.33 & 20.15 & 56 \\
2005 & 1144.50 & 82.50 & 35.90 & 23.90 & 55 \\
2006 & 1236.99 & 81.40 & 36.47 & 22.75 & 78 \\
2007 & 1481.63 & 78.60 & 37.08 & 22.50 & 78 \\
2008 & 1381.90 & 84.00 & 36.00 & 22.00 & 60 \\
2009 & 1526.57 & 87.10 & 38.00 & 23.40 & 72 \\
2010 & 1165.70 & 87.40 & 36.00 & 23.30 & 62 \\
2011 & 1252.80 & 84.00 & 36.00 & 23.00 & 59 \\
2012 & 1617.80 & 81.00 & 32.40 & 23.70 & 60 \\
2013 & 900.00 & 85.90 & 35.50 & 22.80 & 54 \\
2014 & 1016.00 & 92.60 & 37.70 & 21.40 & 55 \\
2015 & 806.00 & 89.60 & 37.30 & 22.50 & 47 \\
2016 & 1747.20 & 82.20 & 35.80 & 21.03 & 83 \\
2017 & 1504.86 & 89.90 & 39.80 & 21.80 & 55 \\
\hline
\end{tabular}

Source: Kwara State Agricultural Development Project, Ilorin, 2018

Table 4. Grain and root tuber yield/ha data for Kwara State (1998-2017)

\begin{tabular}{cccccccccc}
\hline Year & Maize & Sorghum & Rice & Millet & Cowpea & Soya beans & Cassava & Yam & Sweet potato \\
\hline 1998 & 1.14 & 1.30 & 1.84 & 2.08 & 1.15 & 0.61 & 12.90 & 10.98 & 7.12 \\
1999 & 1.25 & 1.62 & 2.70 & 1.98 & 0.94 & - & 13.40 & 11.00 & - \\
2000 & 1.28 & 1.62 & 2.60 & 1.88 & 0.94 & 0.16 & 12.45 & 11.86 & 11.00 \\
2001 & 1.16 & 1.63 & 3.43 & 1.60 & 0.42 & - & 10.79 & 12.96 & 6.19 \\
2002 & 1.30 & 1.70 & 2.77 & 1.03 & 0.69 & - & 12.94 & 12.33 & 8.01 \\
2003 & 1.47 & 1.27 & 3.28 & 104 & 0.72 & - & 12.56 & 10.86 & 7.32 \\
2004 & 1.25 & 1.42 & 2.30 & 2.30 & 0.46 & - & 12.21 & 11.70 & 7.37 \\
2005 & 1.35 & 1.27 & 2.36 & 0.75 & 0.47 & - & 12.46 & 11.63 & 8.50 \\
2006 & 1.58 & 1.32 & 2.37 & 1.82 & 0.50 & - & 15.28 & 11.85 & 8.49 \\
2007 & 1.37 & 1.53 & 2.41 & 1.89 & 0.22 & 1.57 & 16.99 & 11.66 & 8.64 \\
2008 & 1.43 & 1.40 & 2.56 & 1.89 & 0.21 & 1.45 & 17.14 & 12.46 & 8.41 \\
2009 & 1.50 & 1.54 & 3.08 & 1.17 & 0.57 & 1.47 & 15.97 & 12.46 & 8.70 \\
2010 & 1.47 & 1.58 & 3.27 & 1.20 & 0.59 & 1.53 & 16.48 & 12.53 & 9.26 \\
2011 & 1.49 & 1.52 & 2.99 & 1.35 & 0.60 & 1.63 & 16.80 & 13.14 & 9.55 \\
2012 & 1.58 & 1.55 & 2.82 & 1.43 & 0.65 & 1.72 & 16.98 & 13.83 & 9.63 \\
2013 & 1.59 & 3.87 & 2.96 & 1.49 & 0.91 & 1.68 & 17.48 & 14.45 & 9.87 \\
2014 & 1.63 & 3.19 & 3.07 & 1.83 & 0.70 & 1.73 & 17.76 & 15.26 & 10.19 \\
2015 & 1.55 & 2.34 & 3.02 & 1.46 & 0.69 & 1.66 & 16.89 & 13.84 & 9.59 \\
2016 & 1.57 & 2.49 & 2.97 & 1.51 & 0.69 & 1.68 & 17.18 & 14.10 & 9.77 \\
2017 & 1.65 & 2.61 & 3.12 & 1.59 & 0.72 & 1.76 & 14.81 & 14.81 & 10.41 \\
\hline So & Kwa & S & Agi &
\end{tabular}

Source: Kwara State Agricultural Development Project, Ilorin, 2018 


\section{Results and discussion}

\section{Trend of annual rainfall}

Rainfall varies greatly but in an upward manner under the period of study as shown in Figure 2. For instance, year 2016 experienced the maximum rainfall with an annual mean value of $1747.20 \mathrm{~mm}$ while the year 2015 experienced the minimum rainfall with an annual mean value of $806.60 \mathrm{~mm}$. The mean rainfall is $1223.57 \mathrm{~mm}$. Hence, there is an evidence of climatic variability particularly between years 2000 and 2003; also, years 2013 and 2015. The trend of annual number of rainy days revealed that year 2016 recorded the highest number of rainy days (83) while 2015 was lowest with 47 days of rain.

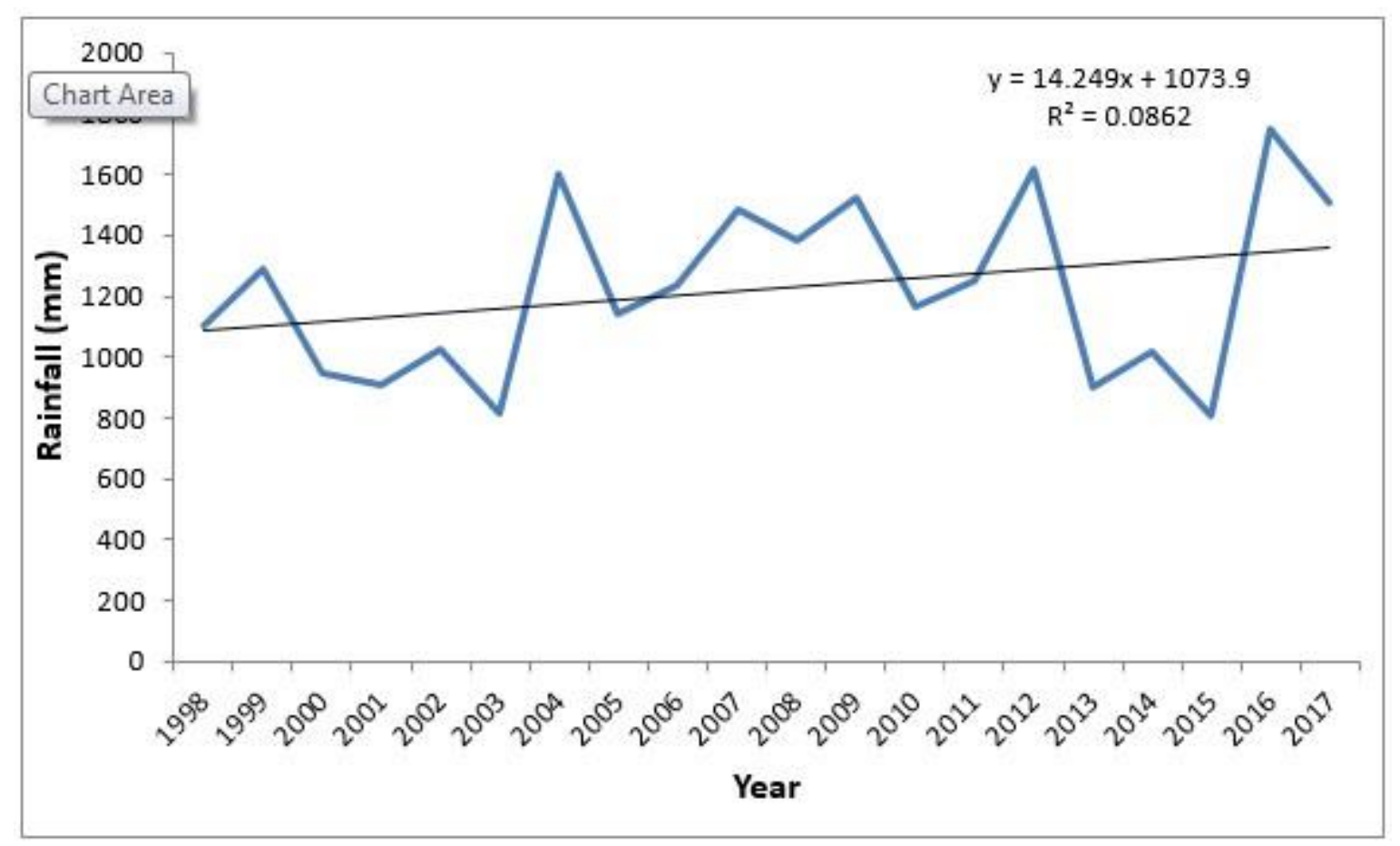

Figure 2. Rainfall pattern in the study area

\section{Trend of annual relative humidity}

Relative humidity does not exhibit so much variation in the year under study as it has maximum value of 92.6 in the year 2014 and lowest in the year 2000 with a value of 76.0 (Figure 3). 


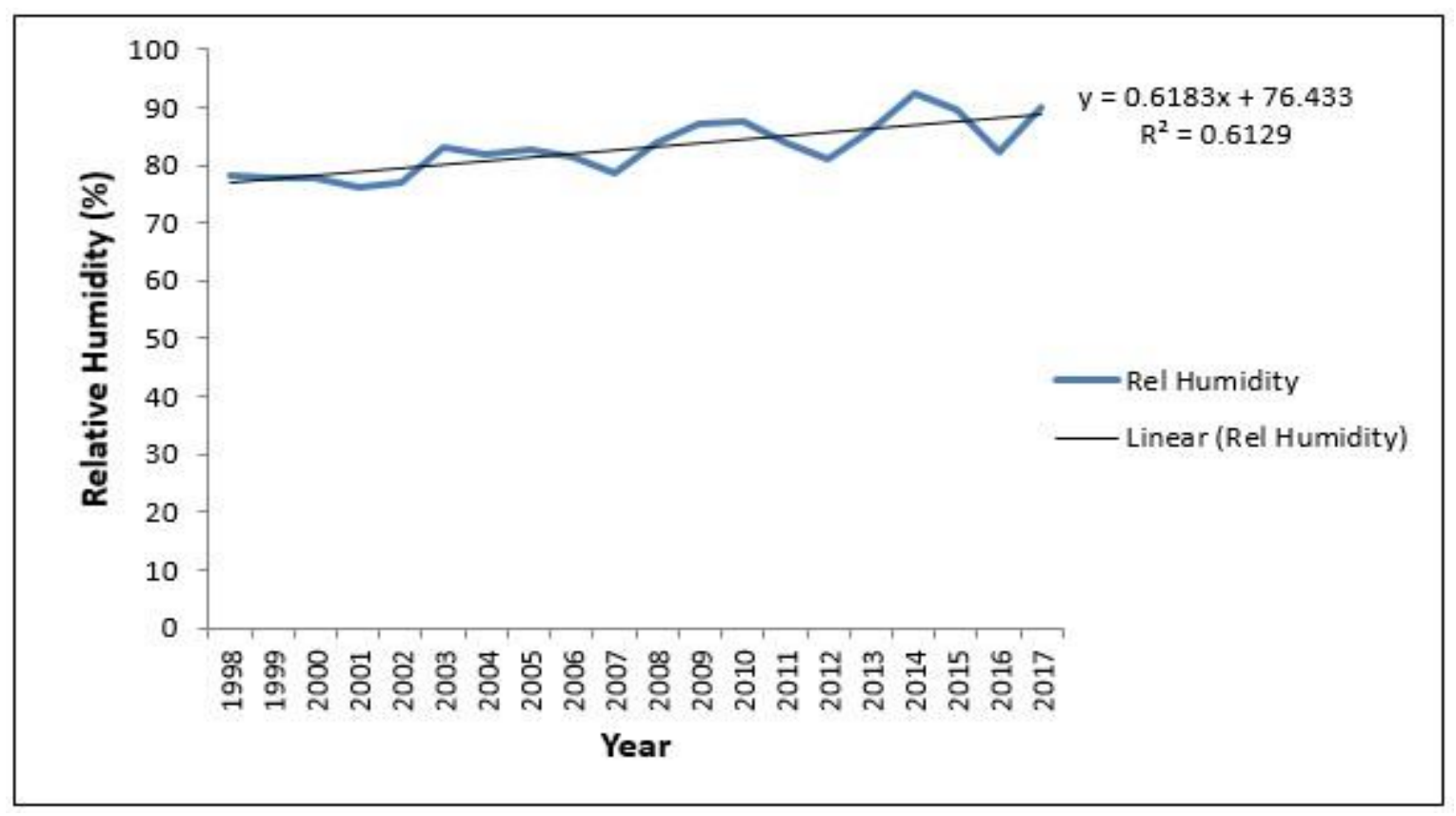

Figure 3. Pattern of relative humidity

\section{Trend of annual temperature}

The average temperature during the study period is $29.4^{\circ} \mathrm{C}$ while the maximum and the minimum are $36.17^{\circ} \mathrm{C}$ and $21.82^{\circ} \mathrm{C}$ respectively. Maximum temperature was highest in the year 2001 with mean annual value of $40.04^{\circ} \mathrm{C}$ and lowest in the year 2003 with mean annual value of $31.17^{\circ} \mathrm{C}$ respectively. Similarly, minimum temperature was highest in the year 2005 with mean annual value of $23.90^{\circ} \mathrm{C}$ and lowest in the year 2003 with mean annual value of $17.50^{\circ} \mathrm{C}$ respectively (see Figure 4).

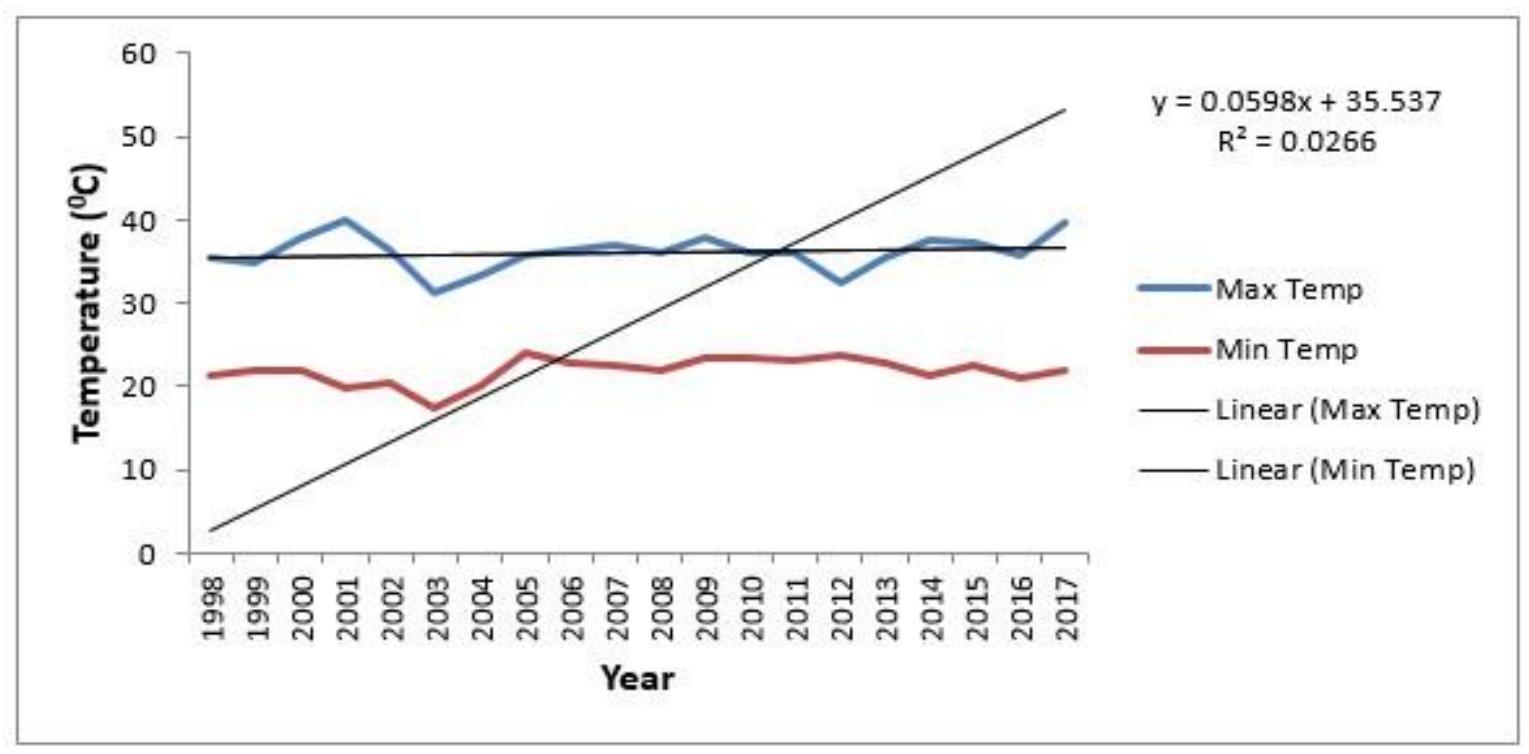

Figure 4. Temperature pattern in the study area 


\section{Trend of grain crop and root tuber yield}

The trend analysis as revealed in Figure 5 indicated that there is no significant variation in maize yield as the highest yield was year 2017 with 1.65 yield/ha and lowest was year 1998 with 1.14yield/ha. This shows an upward trend. Sorghum appears normal until year 2013 when it started increasing. Rice yield was stable until year 2001, 2014 and 2015 when it increases. Highest yield was year 2001 and the lowest yield was in the year 1998. Millet started well with 2.08 but later dropped and highest yield was 2.30 in year 2004. The lowest yield for millet was in year 2005. No significant variation in cowpea and soya beans.

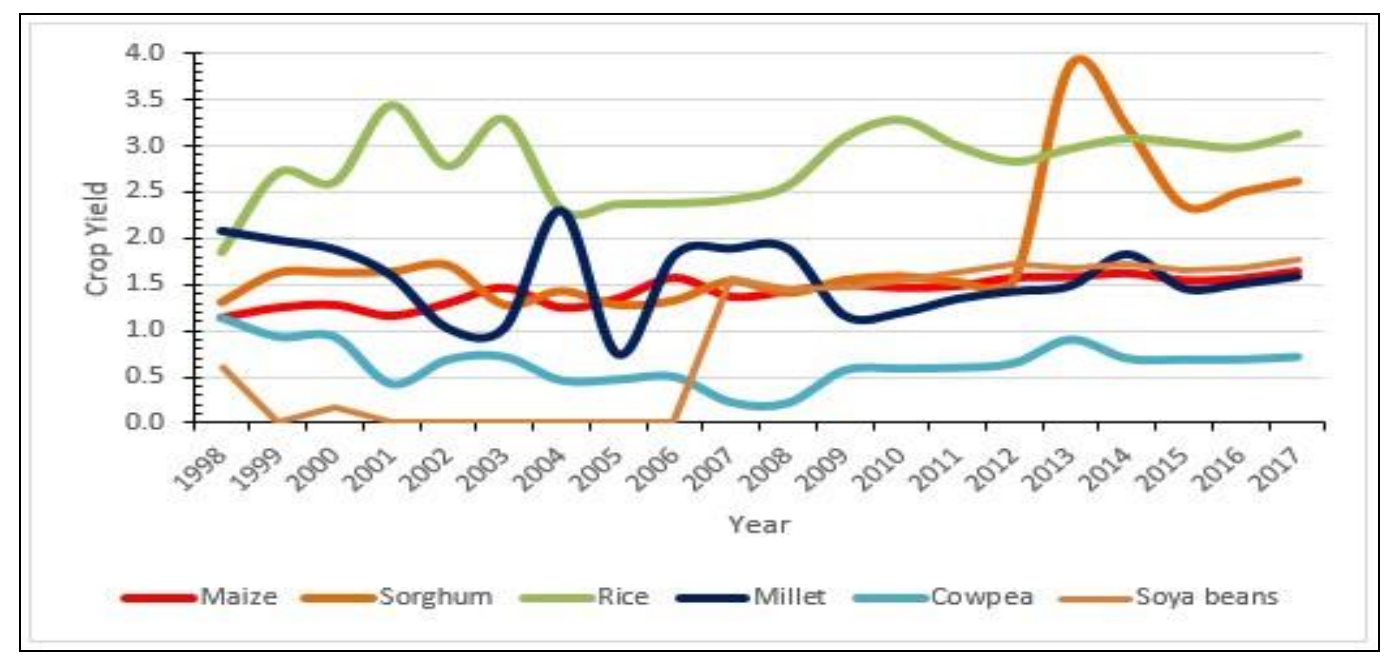

Figure 5. Pattern of grain crops in the study area

From Figure 6, cassava yield is fluctuating under the period of study. It has been an upward trend from 1998 except years 2001 and 2017. Highest yield was year 2014 (17.76) and lowest was year 2001 (10.79). No significant variation in yam yield with an upward trend. Sweet potato was highest and lowest in the year 2001.

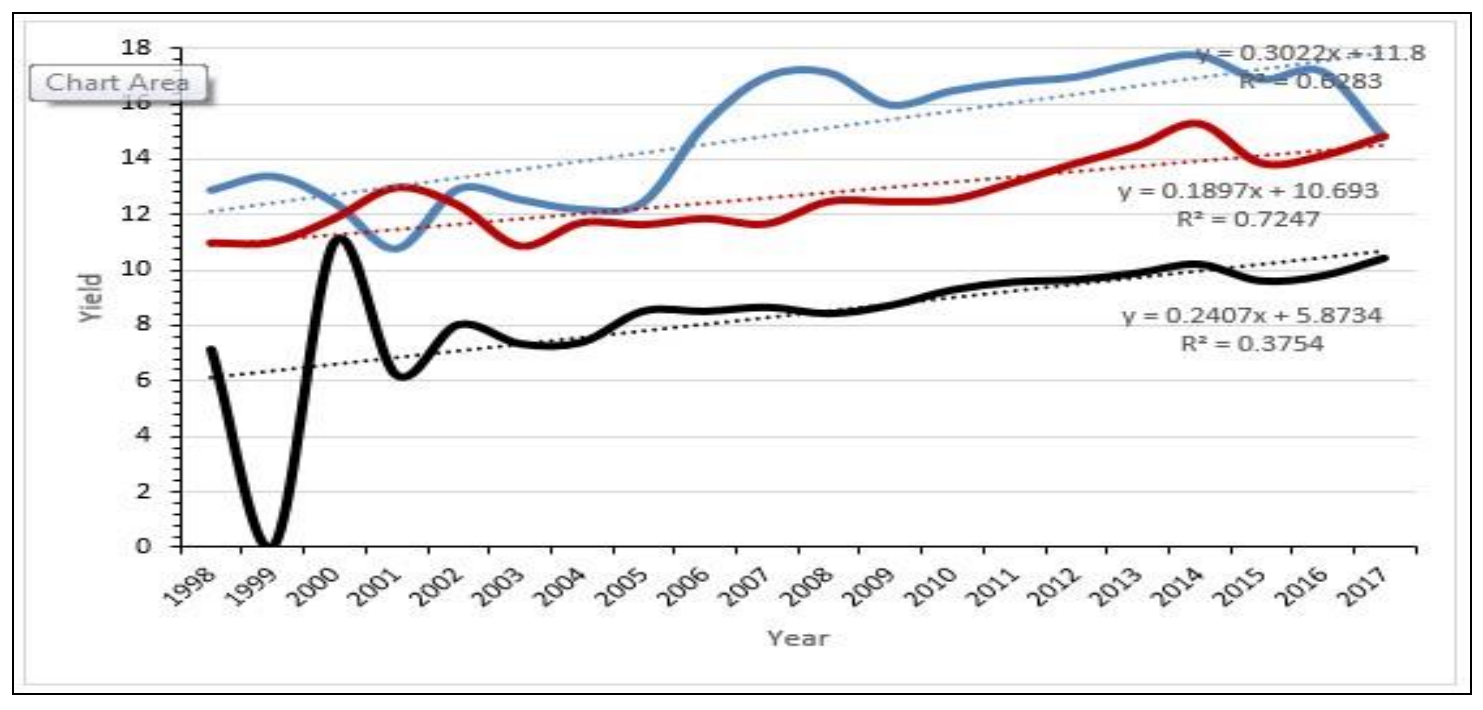

Figure 6. Pattern of root tuber crops in the study area 
Table 5 shows the correlation analysis of the climatic data and grain crop yield data. The results revealed that rainfall is weakly correlated with millet $(0.230)$, maize $(0.180)$, soya beans (0.157), and negatively correlated with sorghum, rice and cowpea. The implication of this is that millet, maize, soya beans, require moderate rainfall to strive well in the study area. Hence, rainfall is not too significant for the negatively correlated crops in the study area. This is similar to the findings by Olanrewaju (2010) that the amount of rainfall received is not as crucial as its spread over time for optimal yield of rice to occur. Relative humidity has a strong and positive correlation with maize $(0.607)$, it correlates with rice $(0.450)$, but weakly correlate with sorghum (0.269), soya beans $(0.183)$ and negatively correlated with the remaining crops. This is in support of Ajadi et al. (2011) that relative humidity has a negative correlation with sorghum, rice and cowpea. Maximum temperature correlates with rice $(0.512)$, weakly correlated with sorghum (0.264), soya beans (0.264), millet (0.067) and maize (0.001). It correlates negatively with cowpea. The negatively correlation implies that the crops do not really need maximum temperature for its yield. This corroborates the findings of Olanrewaju and Tunde (2010) that maximum temperature shows a strong negative relationship with cowpea. Minimum temperature correlates with soya beans $(0.438)$, maize $(0.315)$, rice $(0.181)$ but negatively correlated with millet (-0.121) and cowpea (-0.098). The implication of this is that rice does not require minimum temperature for their yield. This is against the findings of Akpenpuum (2013) that rice and millet correlate strongly with rainfall and minimum temperature. Number of rainy days weakly correlates with millet $(0.254)$ but negatively correlated with the remaining crops under study. This means number of rainy days is not a significant factor for crop yield in the study area.

Table 5. Correlation analysis for climatic elements and grain crops

\begin{tabular}{lccccc}
\hline Crops & $\begin{array}{c}\text { Rainfall } \\
(\mathbf{m m})\end{array}$ & $\begin{array}{c}\text { Relative } \\
\text { humidity }\end{array}$ & $\begin{array}{c}\text { Max. temperature } \\
\left({ }^{\mathbf{O}} \mathbf{C}\right)\end{array}$ & $\begin{array}{c}\text { Min. temperature } \\
\left({ }^{\mathbf{O}} \mathbf{C}\right)\end{array}$ & $\begin{array}{c}\text { Number of } \\
\text { rainy days }\end{array}$ \\
\hline Maize & 0.180 & 0.607 & 0.001 & 0.315 & -0.145 \\
Sorghum & -0.161 & 0.269 & 0.264 & 0.072 & -0.231 \\
Rice & -0.029 & 0.450 & 0.512 & 0.181 & -0.196 \\
Millet & 0.230 & -0.400 & 0.067 & -0.121 & 0.254 \\
Cowpea & -0.326 & -0.550 & -0115 & -0.098 & -0.005 \\
Soya beans & 0.157 & 0.183 & 0.264 & 0.438 & -0.071 \\
\hline
\end{tabular}

*Correlation is significant at the 0.05 level (2 tailed)

From Table 6, rainfall is weakly correlated with cassava (0.289), yam (0.085) and sweet potato (0.019). The implication of this is that cassava, yam, and sweet potato, require moderate rainfall to strive well in the study area. Relative humidity has a strong and positive correlation with sweet potato (0.742), but weakly correlates with cassava (0.364) and yam (0.085). Maximum temperature correlates weakly with yam (0.373), sweet potato (0.229) and cassava (0.013). Minimum temperature correlates with cassava (0.516), sweet potato (0.269) and yam (0.224). This implies that these root tubers do not require minimum temperature for their yield. Number of rainy days weakly correlates with cassava (0.119) but negatively correlated with the remaining root tubers under study. This means number of rainy days is not a significant factor for root tuber crop yield in the study area. 
Table 6. Correlation analysis for climatic elements and root tuber

\begin{tabular}{lccccc}
\hline Root Tuber & Rainfall $(\mathbf{m m})$ & $\begin{array}{c}\text { Relative } \\
\text { humidity }\end{array}$ & $\begin{array}{c}\text { Max. temperature } \\
\left({ }^{\mathbf{O}} \mathbf{C}\right)\end{array}$ & $\begin{array}{c}\text { Min. temperature } \\
\left({ }^{\circ} \mathbf{C}\right)\end{array}$ & $\begin{array}{c}\text { Number of } \\
\text { rainy days }\end{array}$ \\
\hline Cassava & 0.289 & 0.364 & 0.013 & 0.516 & 0.119 \\
Yam & 0.085 & 0.085 & 0.373 & 0.224 & -0.298 \\
Sweet Potato & 0.019 & 0.742 & 0.299 & 0.269 & -0.374 \\
\hline
\end{tabular}

*Correlation is significant at the 0.05 level (2 tailed)

The result of the regression analysis on Table 7 reveals that $47 \%, 15 \%, 40 \%, 30 \%, 42 \%$ and $26 \%$ of the variance in maize, sorghum, rice, millet, cowpea and soya beans respectively be explained by the climatic elements under study. The implication is that $53 \%, 85 \%, 60 \%, 70 \%$, $58 \%$ and $74 \%$ of the variance in the crops under study can be explained by some other factors such as edaphic factors, farm techniques and seed varieties. This is in support of Ajadi et al. (2011) that variation in crop yield could not only be attributed to the impact of changes in climatic elements but also to some other non-climatic factors such as soil fertility and farm techniques.

Table 7. Regression analysis for grains

\begin{tabular}{lcccccc}
\hline Crops & $\mathbf{R}$ & $\mathbf{R}^{\mathbf{2}}$ & $\begin{array}{c}\text { Standard } \\
\text { error }\end{array}$ & $\begin{array}{c}\text { Regression } \\
\text { coefficient }\end{array}$ & $\mathbf{F}$ & P-value \\
\hline Maize & 0.687 & 0.472 & 0.13400 & 1.385 & 2.500 & 0.018 \\
Sorghum & 0.387 & 0.150 & 0.75520 & -0.232 & 0.493 & 0.776 \\
Rice & 0.636 & 0.404 & 0.35926 & -0.483 & 1.901 & 0.158 \\
Millet & 0.551 & 0.303 & 0.38811 & 0.593 & 1.216 & 0.352 \\
Cowpea & 0.650 & 0.422 & 0.20684 & 1.565 & 2.045 & 0.134 \\
Soya beans & 0.518 & 0.268 & 0.82439 & -1.481 & 1.025 & 0.440 \\
\hline
\end{tabular}

Similarly, from the regression Table $8,44 \%, 42 \%$, and $60 \%$ of the variance in cassava, yam, and sweet potato respectively can be explained by the climatic elements under study. The implication is that $56 \%, 58 \%$ and $40 \%$ of the variance in the crops under study can be explained by some other factors. It thus implies that there is no significant difference in impact of changes in climatic elements between grains and root tubers in the study area. This is in support of the findings by Elijah et al. (2018) that climate change does not have significant effect on the production of certain root crops.

Table 8. Regression analysis for root tubers

\begin{tabular}{lcccccc}
\hline Crops & R & $\mathbf{R}^{2}$ & $\begin{array}{c}\text { Standard } \\
\text { error }\end{array}$ & $\begin{array}{c}\text { Regression } \\
\text { coefficient }\end{array}$ & F & P-value \\
\hline Cassava & 0.666 & 0.443 & 1.96038 & 0.007 & 2.230 & 0.109 \\
Yam & 0.649 & 0.421 & 1.16917 & 0.620 & 2.033 & 0.136 \\
Sweet Potato & 0.775 & 0.601 & 1.70979 & -0.542 & 4.223 & 0.015 \\
\hline
\end{tabular}

\section{Conclusion}

The study has to a large extent revealed that changes in climatic elements have an impact on both grains and root tuber yield and production in the study area. Hence there is no significant 
difference of impacts of changes in climatic elements between grains and root tuber. The paper thus concluded that changes in climatic elements can be seen as part of the factors responsible for low agricultural yield and production in the state and country at large. Policies that will improve the status of agricultural yield and production should therefore, be embarked upon. Farmers in the study area should be sensitized and trained in the area of climatic variability adaptation and mitigation. Programs that can minimize the adverse effects of greenhouse gases should also be embarked upon. Furthermore, to improve agricultural yield and production in the State and country generally, the use of modern techniques should be adopted. Additionally, soil fertility can be improved through the use of fertilizers.

\section{References}

Ajibade, L.T. (2002). Indigenous systems of land evaluation in the Yoruba Speaking Area of Kwara State (PhD dissertation). Retrieved from Department of Geography, Obafemi Awolowo University (OAU), Ile-Ife, Osun State, Nigeria.

Ajadi, B.S., Adeniyi, A., \& Tunde, A.M. (2011). Impact of climate on urban agriculture. A case study of Ilorin City. Global Journal of Human \& Social Sciences, 2(1), 25-30.

Akpenpuum, T.D. (2013). Climate and grain crops yield in Kwara State, Nigeria. Journal of Emerging Trends in Engineering and Applied Sciences, 4(5), 737-741.

Ayantoye, K., Yusuf, S.A., Omonona, B.T., \& Amao, J.O. (2011). Food security dynamics and its correlates among rural households in South-western Nigeria. International Journal of Agricultural Development, 4(1), 43-56.

Ayoade. (2004). Introduction to climatology for the Tropics. Ibadan, Spectrum Book Limited.

Barry, R.G., \& Chorley, R.J. (2003). Atmosphere, weather and climate, London and New York, Routledge.

Chen, S., \& Ravallion, M. (2007). Absolute poverty measures for the developing world, 19812004. PNAS, 104(43), 16757-167562.

Elijah, S.T., Osuafor, O.O., \& Anarah, S.E. (2018). Effects of climate change on yam production in Cross River State, Nigeria. International Journal of Agriculture and Forestry, 8(2), 104111. http://dx.doi.org/10.5923/j.ijaf.20180802.09.

Hovorka, A.J., \& Lee-Smith, D. (2004). Gendering the urban agriculture: Agenda in Veenhuizen (Eds.), Cities farming for the future (pp. 578). Urban agriculture for green and productive cities. International Institute of Rural Reconstruction and ETC Urban Agriculture. Retrieved from http://pdfs.semanticscholar.org

Ismaiala, U., Gana, A.S., Tswanya, N.M., \& Dogara, D. (2010). Cereals production in Nigeria: Problems, constraints and opportunities betterment. African Journal of Agricultural Research, 5(12), 1341-1350. http://dx.doi.org/10.5897/AJAR09.407

International Institute for Sustainable Development (IISD). (2007). Community based adaptation to climate change Bulletin. A summary of the second International Workshop on Community-Base Adaptation to Climate Change. IISD Reporting Services.

Kurukulasuriya, P., \& Rosenthal, S. (2003). Climate change and agriculture: A review of impacts and adaptations (Paper No. 91). Retrieved from Climate Series, Agriculture and Rural Development Department and Environmental Department, World Bank, Washington, D.C. website: http://documents.worldbank.org 
Kurukulasuriya, P., \& Mendelsohn, R. (2008a). A Ricardian Analysis of the impact of Climate Change on African Cropland. African Journal of Agriculture and Resource Economics, 2(1), $1-23$.

Kwara State Ministry of Lands. (2017). Map of Kwara State.

Kwara State Agricultural Development Project (KWADP) (2018) Mean Annual Climatic and Crop Yield Data for Kwara State (1998-2017).

Lobell, D.B., \& Burke, M.B. (2008). Why are Agricultural impacts of Climate Change so uncertain? The importance of temperature relative to precipitation. Environmental, Research Letters, 3(3), 1-8. http://dx.doi.org/10.1088/1748-9326/3/3/034007.

Nguyen, N.V. (2006). Global climate changes and rice food security FAO, Rome. Retrived from http://wwwfao.org.

Olanrewaju, R.M., \& Tunde, A.M. (2010). Climate effects on cowpea production in the Derived Savanna Ecological Zone of Nigeria: A comparative study of two agricultural zones in Kwara State. In Akoshile, C.O., Adeloye, A.A., Fayeye, T.R., \& Ajibola, T.B. (Eds.), Nigerian Meteorological Society. Proceeding of the National Conference 2010 Climate Change Impact and Adaptation: Is Nigeria Ready? November 1-4, Ilorin, Nigeria.

Olanrewaju, R.M. (2010). Climate and rice production in a part of the Niger River Basin Development Authority Area (NRBDA): A case study of Edu and Lafiagi Local Government Areas of Kwara State, Nigeria. Journal of Meteorology \& Climate Science, $8(2), 102-110$.

Thompson, O.A., \& Amos, T.T. (2010). Climatic change and food security in Nigeria. Journal of Meteorology \& Climate Science. 8(2), 91-101. http://dx.doi.org/10.1016/b978-0-444-889126.50011-6

US Global Change Research Program. (2003). Food, agriculture, and climate change: The U.S. and International Outlook. Retrieved from http://www.usgcrp.gov. 